Please do not remove this page

RMIT

UNIVERSITY

\title{
Development of nano-structured titanium oxide thin films using a gas carving technique
}

Dhawan, Deepak; Sabri, Ylias; Bhargava, Suresh; Sood, Dinesh; Kalantar-Zadeh, Kourosh

https://researchrepository.rmit.edu.au/esploro/outputs/9921862787501341/filesAndLinks?institution=61RMIT_INST\&index=null

Dhawan, D., Sabri, Y., Bhargava, S., Sood, D., \& Kalantar-Zadeh, K. (2006). Development of nano-structured titanium oxide thin films using a gas carving technique. Proceedings of SPIE, the International Societey for Optical Engineering. https://doi.org/10.1117/12.695539

Document Version: Published Version

Published Version: https://doi.org/10.1117/12.695539

Repository homepage: https://researchrepository.rmit.edu.au

(C) 2006 SPIE

Downloaded On 2023/04/26 23:19:57 +1000

Please do not remove this page 
Thank you for downloading this document from the RMIT Research Repository.

The RMIT Research Repository is an open access database showcasing the research outputs of RMIT University researchers.

RMIT Research Repository: http://researchbank.rmit.edu.au/

\section{Citation:}

Dhawan, D, Sabri, Y, Bhargava, S, Sood, D and Kalantar-Zadeh, K 2006, 'Development of nano-structured titanium oxide thin films using a gas carving technique', in D. Milam (ed.) Proceedings of SPIE, the International Societey for Optical Engineering, Adelaide, Australia, 11-13 December 2006.

See this record in the RMIT Research Repository at:

http://researchbank.rmit.edu.au/view/rmit:2386

Version: Published Version

Copyright Statement: (C) 2006 SPIE

Link to Published Version:

http://dx.doi.org/10.1117/12.695539 


\title{
Development of nano-structured titanium oxide thin films using a gas carving technique
}

\author{
Deepak Dhawan*a $^{*}$, Ylias Sabri ${ }^{\mathrm{b}}$, Suresh Bhargava ${ }^{\mathrm{b}}$, Dinesh Sood ${ }^{\mathrm{a}}$, K. Kalantar-Zadeh ${ }^{\mathrm{a}}$ \\ ${ }^{a}$ Microelectronics and Materials Technology Centre, School of Electrical and computer Engineering, \\ RMIT University, 376 Swanston Street, Melbourne, VIC 3001, Australia \\ ${ }^{b}$ Dept. of Applied Chemistry, RMIT Univ./City Campus, 124 La Trobe Street, Melbourne, Australia
}

\begin{abstract}
A method is developed for producing nano-structured titanium oxide thin films using $\mathrm{H}_{2}$ gas interaction with titanium thin film at a high temperature. These nano-structured thin films have been formed on a quartz crystal substrate. Titanium (Ti) thin films were deposited on the quartz crystal using a RF magnetron sputterer. The samples were placed in the oven at $500-800^{\circ} \mathrm{C}$ for 5 hours. The gas mixture of $1 \% \mathrm{H}_{2}$ in $\mathrm{N}_{2}$ was introduced in the oven. The process of Ti annealing in the presence of $\mathrm{H}_{2}$ carves Ti films into nano-structure shapes. The process is a gas-solid interaction. Thin films were characterised using Scanning Electron Microscopes (SEM) and X-Ray Diffraction (XRD) technique. The nano structures formed have dimensions in a range of $25 \mathrm{~nm}-150 \mathrm{~nm}$ obtained after gas carving.
\end{abstract}

Keywords: Nanostructures, titanium, $\mathrm{H}_{2}$, thin film

\section{INTRODUCTION}

Micro and nano structured thin films have received considerable attention in recent years due to their high potential for commercial and technological applications. These materials have utilization in optical, electrical, and micromechanical devices. These nano-structures are promising, especially for the preparation of large surface to volume area with high aspect ratios, which are difficult to form by lithographic processes when dimensions approach features of less than $100 \mathrm{~nm}$.

One of the materials, with plenty of applications in nanostructure form, is titanium oxide. It is the most widely used white pigment because of its brightness and very high refractive index [1]. When it is deposited as a thin film, its refractive index and colour make it an excellent reflective optical coating for the development of dielectric mirrors. In cosmetic and skin care products, titanium dioxide is used both as a pigment and a thickener. It is also an effective opacifier in powder form. Titanium dioxide is a photocatalyst under ultraviolet light. Additionally, it offers possibilities in the development of gas sensors and solar cells [2]. $\mathrm{TiO}_{2}$ is one of the most important engineering materials which has been used in chemical sensors [3, 4]. Titanium oxide in the shape of nanowires [5] [6] and nanoporous structures [7] is desirable for these applications because of its large surface area. Larger surface area provides more active sites for enhanced molecular interaction, high surface activity and high sensitivity.

Several approaches have been explored for modifying the surface morophology of titania by several researchers. Imhof and Pine reported macroporous material of titania, silica and zirconia by using the emulsion droplets as templates around which material is deposited through sol-gel process [8]. Pan et al. reported ultra-long nano-belt of zinc, tin and indium oxide by evaporating commercial metal oxide powder at high temperature [9] and Sehaoon et al. reported producing of titania surfaces compromised of nanofibres by reaction with gases at high temperature [10].

The increased demand for nanostructured materials is often complicated by the conflicting demands for precise control of fine features and for large scale mass production [10]. In this paper, we developed a simple method by using titanium thin films to produce nanostructures titanium oxides by gas carving technique. Titanium thin films were deposited using a

Micro- and Nanotechnology: Materials, Processes, Packaging, and Systems III, edited by Jung-Chih Chiao, Andrew S. Dzurak, Chennupati Jagadish, David Victor Thiel, Proc. of SPIE Vol. 6415, 641514, (2006) - 0277-786X/06/\$15 - doi: 10.1117/12.695539 
RF magnetron sputterer. The effect of gas carving process on titanium is investigated by studying the electron microscopy (SEM) images and X-Ray diffraction (XRD) graphs.

\section{EXPERIMENTAL}

\subsection{Titanium Thin Film Deposition}

Ti films of $2 \mu \mathrm{m}$ thickness were sputtered on the smooth surface of the polished quartz crystal substrates using a RF magnetron sputterer. For cleaning, the samples were rinsed in acetone, isopropanol and with deionised water before placing in the chamber. The chamber of the sputterer was evacuated to a pressure of $10^{-3} \mathrm{~Pa}$. The distance between the target and sample was $80 \mathrm{~mm}$. Power of $120 \mathrm{~W}$ was used and argon gas was introduced in the sputerring chamber at a pressure of $1.33 \mathrm{~Pa}$. During the process the samples were heated at elevated temperatures of $120^{\circ} \mathrm{C}$.

\subsection{Characterization of Ti thin film}

Morphology of Ti thin films was investigated using SEM and XRD. Figure 1 shows the SEM image of the surface of the titanium thin film. It shows that the crystallites of titanium film are densely packed and consists of nano polygonal shapes. Most of these polygonal have dimensions of less than $100 \mathrm{~nm}$.

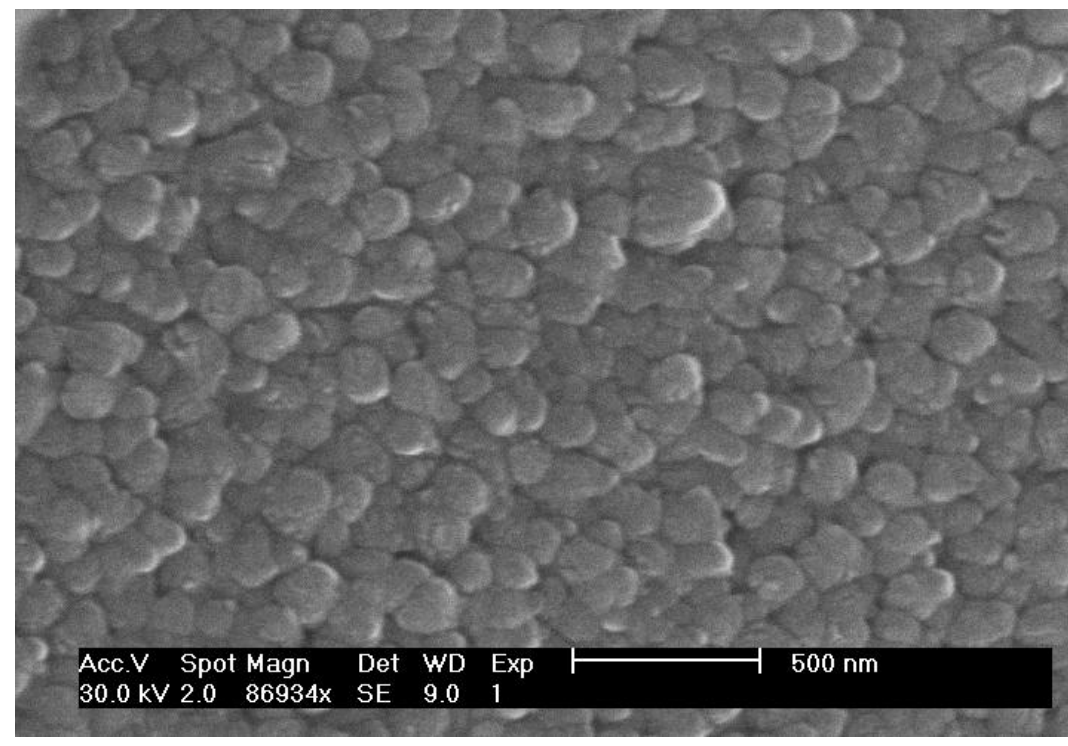

Figure 1 SEM image of the titanium film surface sputtered on quartz

Figure 2 shows the XRD pattern for Ti film before carving. It shows that the dominant faces are $[0,0,2],[1,0,2]$ and $[1,0,3]$. 


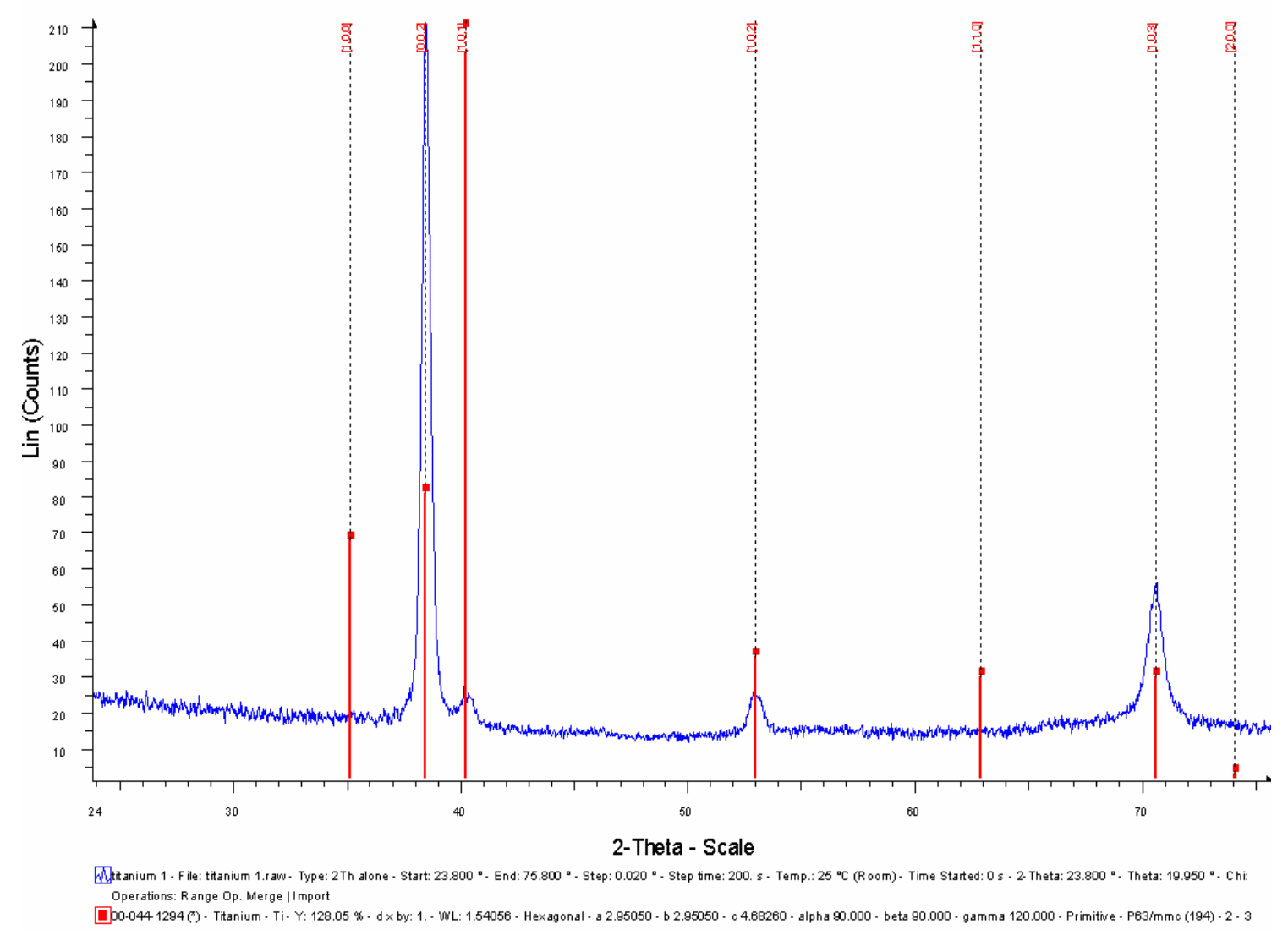

Figure 2 XRD pattern of titanium film on quartz

\subsection{Gas carving of Ti films}

The gas carving process was conducted in a temperature range of between $500^{\circ} \mathrm{C}$ to $800^{\circ} \mathrm{C}$. A combination of $1 \% \mathrm{H}_{2}$ in $\mathrm{N}_{2}$ was used as the etchant. Flow rate was approximately $250 \mathrm{ml} /$ minute. The process lasted for 5 hours.

\subsection{SEM images of thin films}

\section{RESULTS AND DISCUSSION}

Figure 3, Figure 4 and Figure 5 shows the SEM images of the surface of the titanium etched at $640^{\circ} \mathrm{C}$. The resulted thin film consist of nanorods and nanostructures having one of the dimensions in the order of $20-150 \mathrm{~nm}$. 


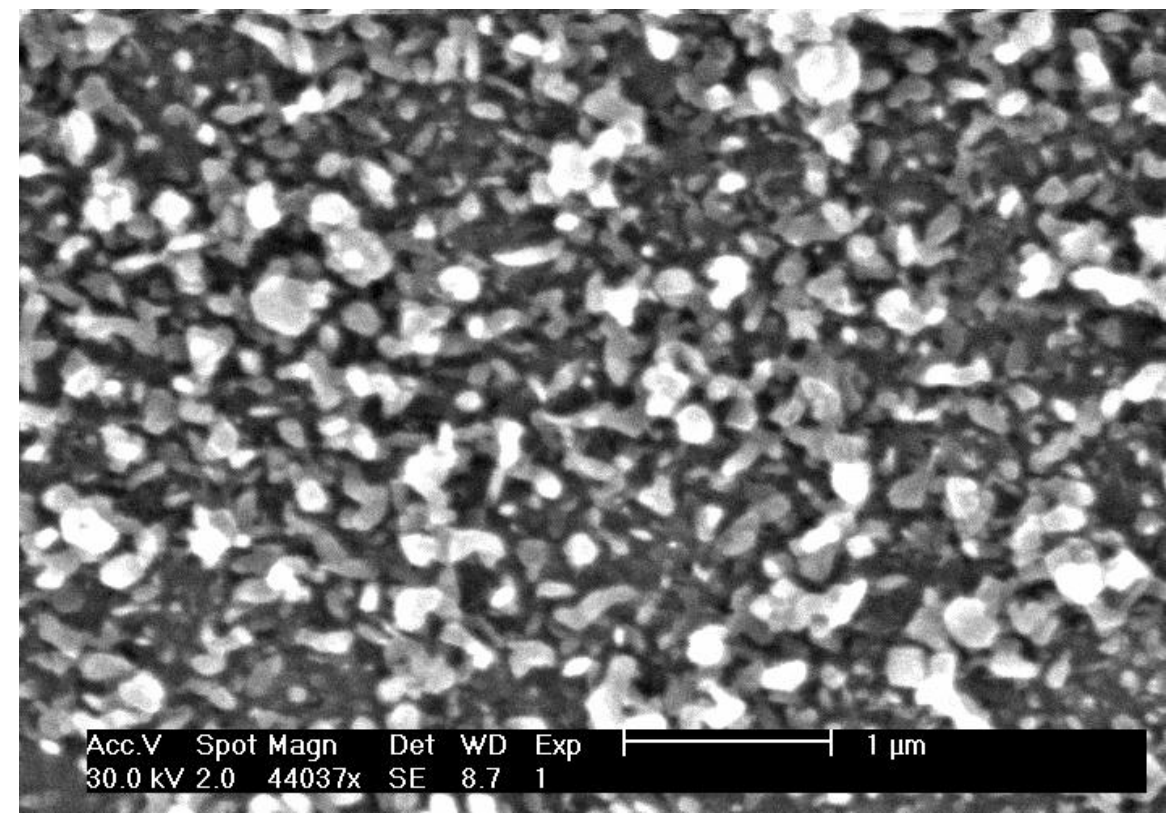

Figure 3 Titanium film surface carved at $640^{\circ} \mathrm{C}$

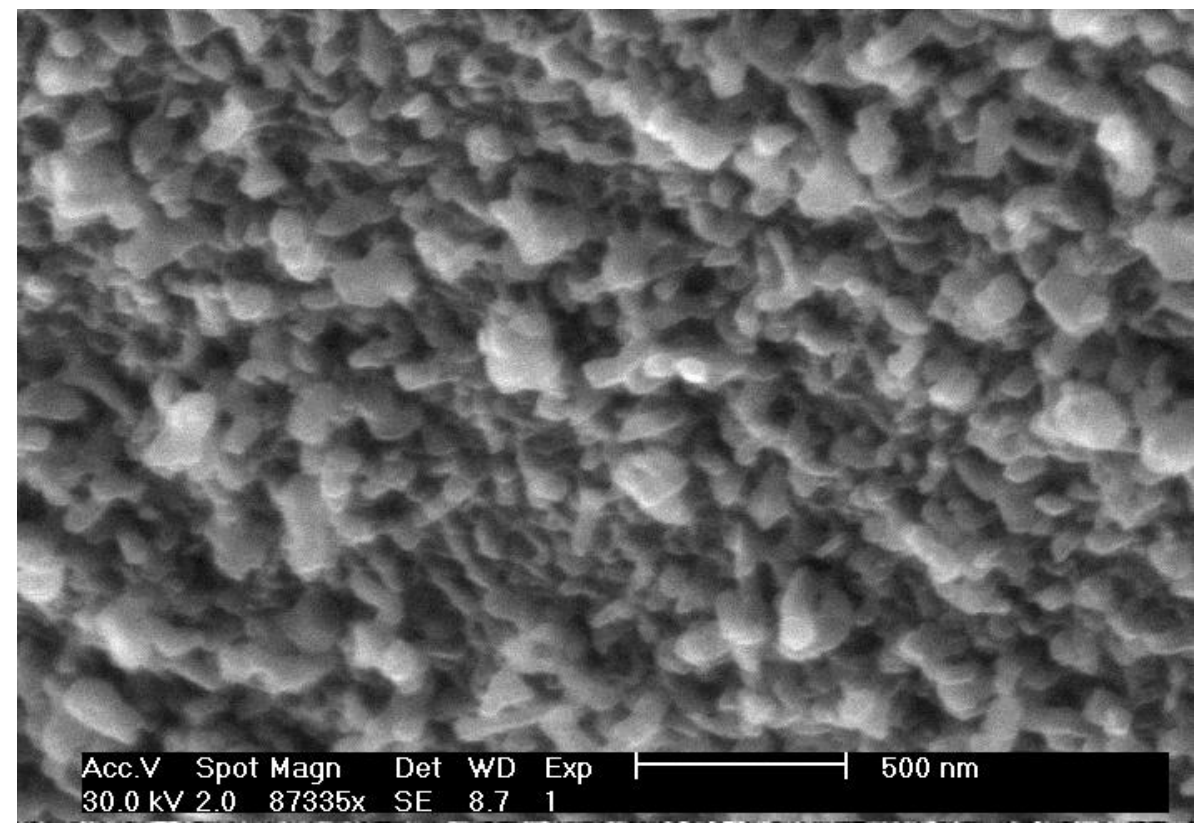

Figure 4 Titanium film surface carved at $640^{\circ} \mathrm{C}$ (shown at $45^{\circ}$ angle) 


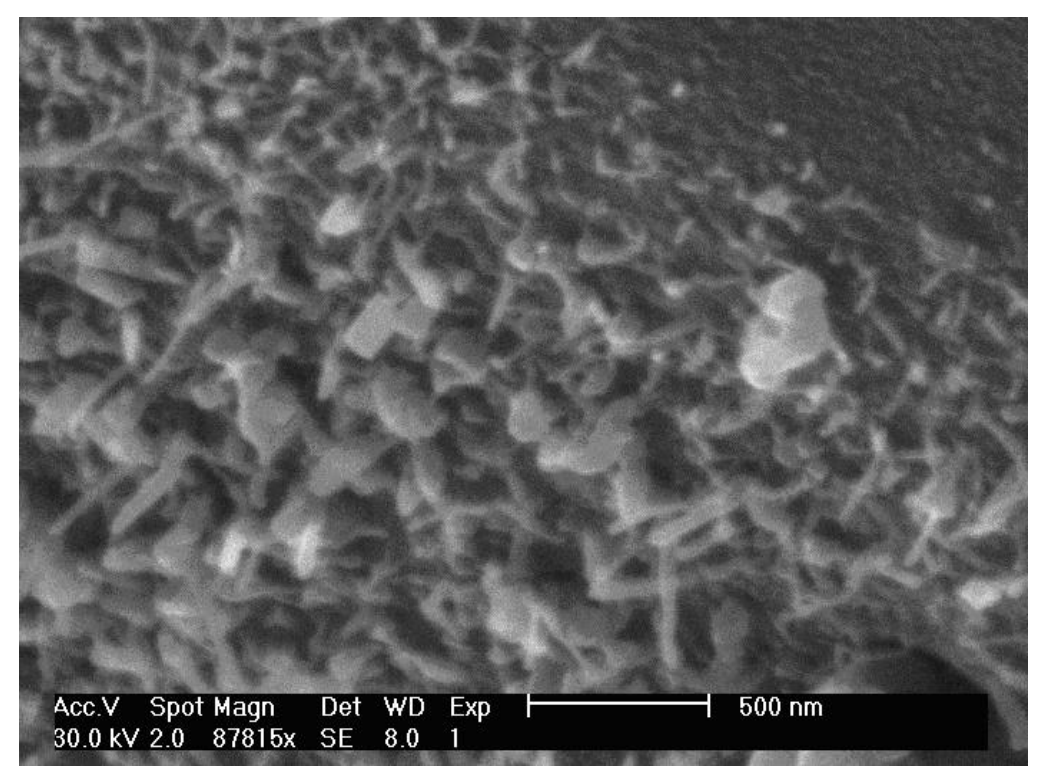

Figure 5 Titanium film surface carved at $640^{\circ} \mathrm{C}$ (shown at $45^{\circ}$ angle)

Figure 6 and Figure 7 shows the SEM images of the surface of the titanium etched under 1\% hydrogen in nitrogen. The samples were etched at $700^{\circ} \mathrm{C}$. The figure shows that the titanium film forming crystals with spacing and dimensions in the range of $70-150 \mathrm{~nm}$.

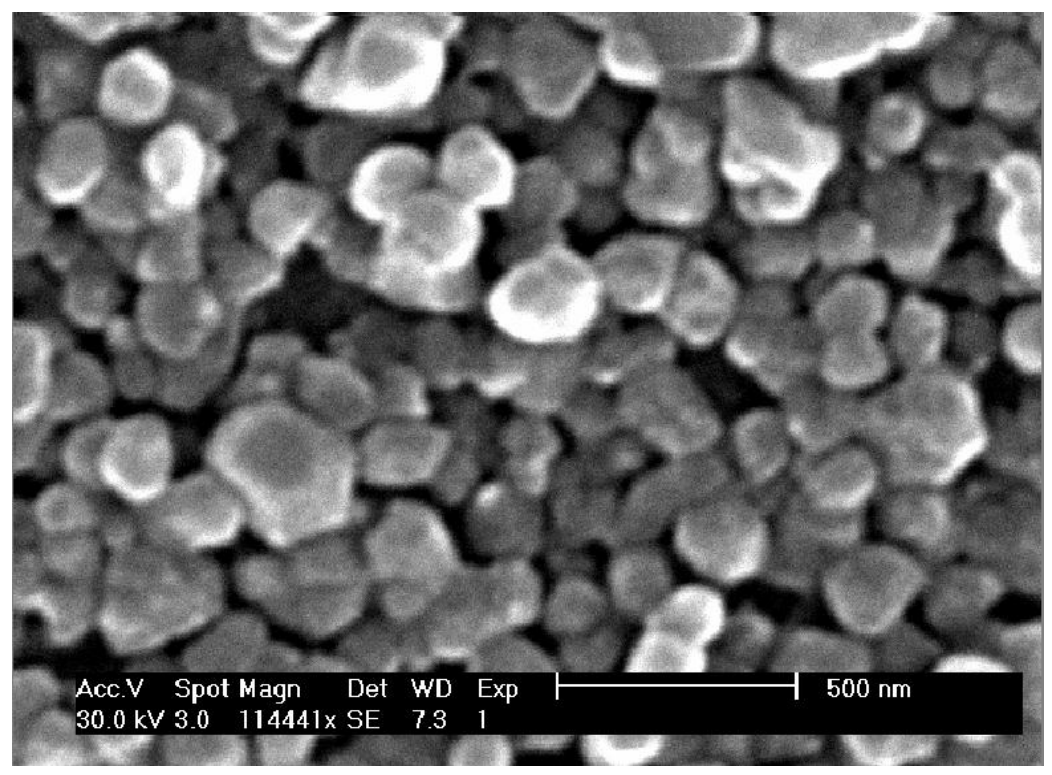

Figure 6 Titanium film surface carved at $700^{\circ} \mathrm{C}$ 


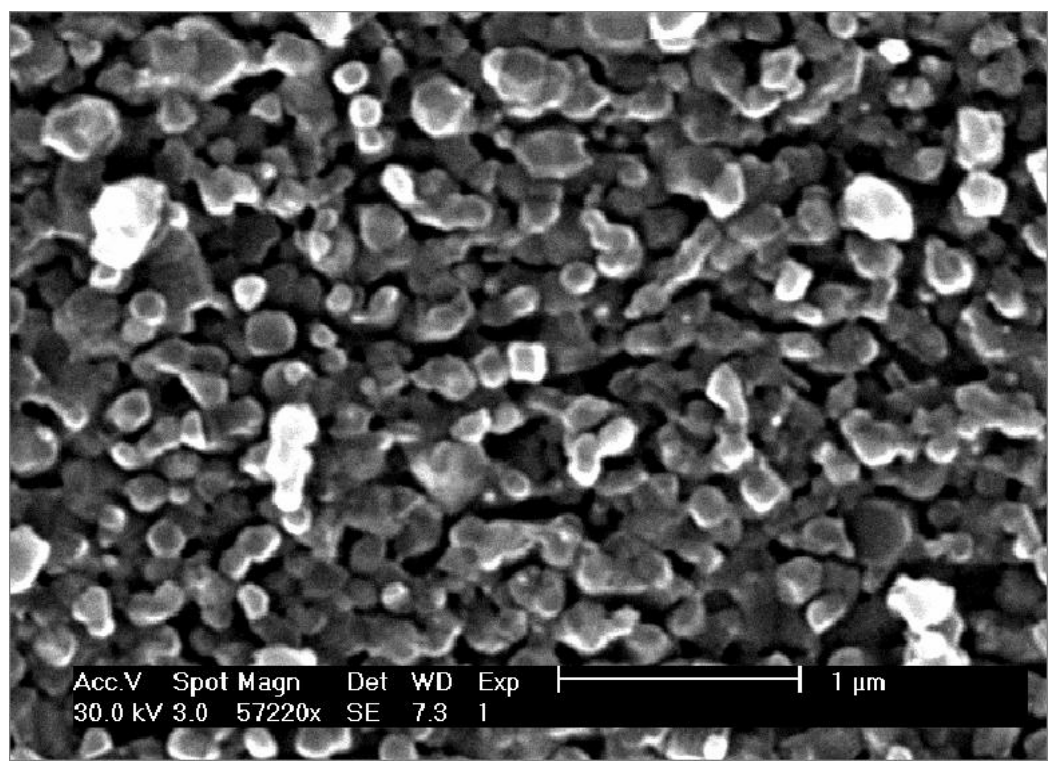

Figure 7 Titanium film surface carved at $700^{\circ} \mathrm{C}$

Figure 8 and Figure 9 shows the different scale SEM images of the surface of the titanium etched under 1\% hydrogen in nitrogen this time at $800^{\circ} \mathrm{C}$. The etched titanium consists of structures consists of nano plates with thickness in an order of a few $10^{\text {th }}$ of $\mathrm{nm}$ and having other dimensions less than $100 \mathrm{~nm}$.

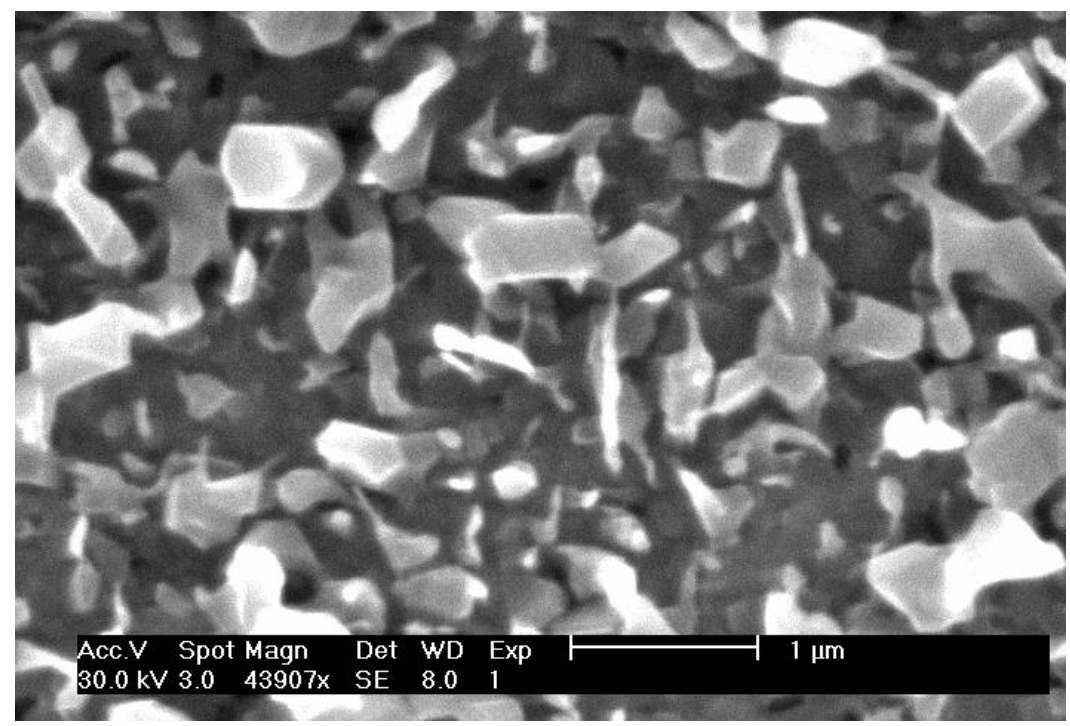

Figure 8 Titanium film surface carved at $800^{\circ} \mathrm{C}$ 


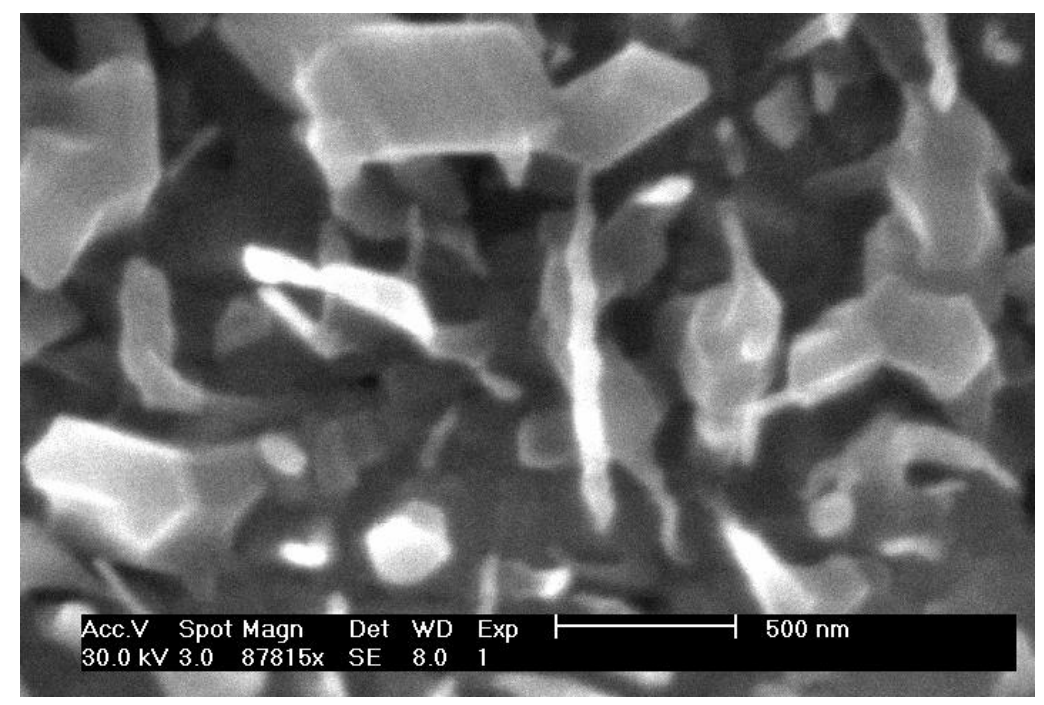

Figure 9 Titanium film surface carved under hydrogen at $800^{\circ} \mathrm{C}$

\subsection{XRD patterns of the etched films}

Figure 10 shows the XRD pattern for the sample carved at $700^{\circ} \mathrm{C}$. The XRD patterns for other temperatures are fairly similar. It reveals that thin films have changed into rutile form of titanium dioxide. The dominant faces of the rutile form are $[1,1,0],[1,0,1],[1,1,0],[1,1,1],[2,1,1]$ and $[2,2,0]$.

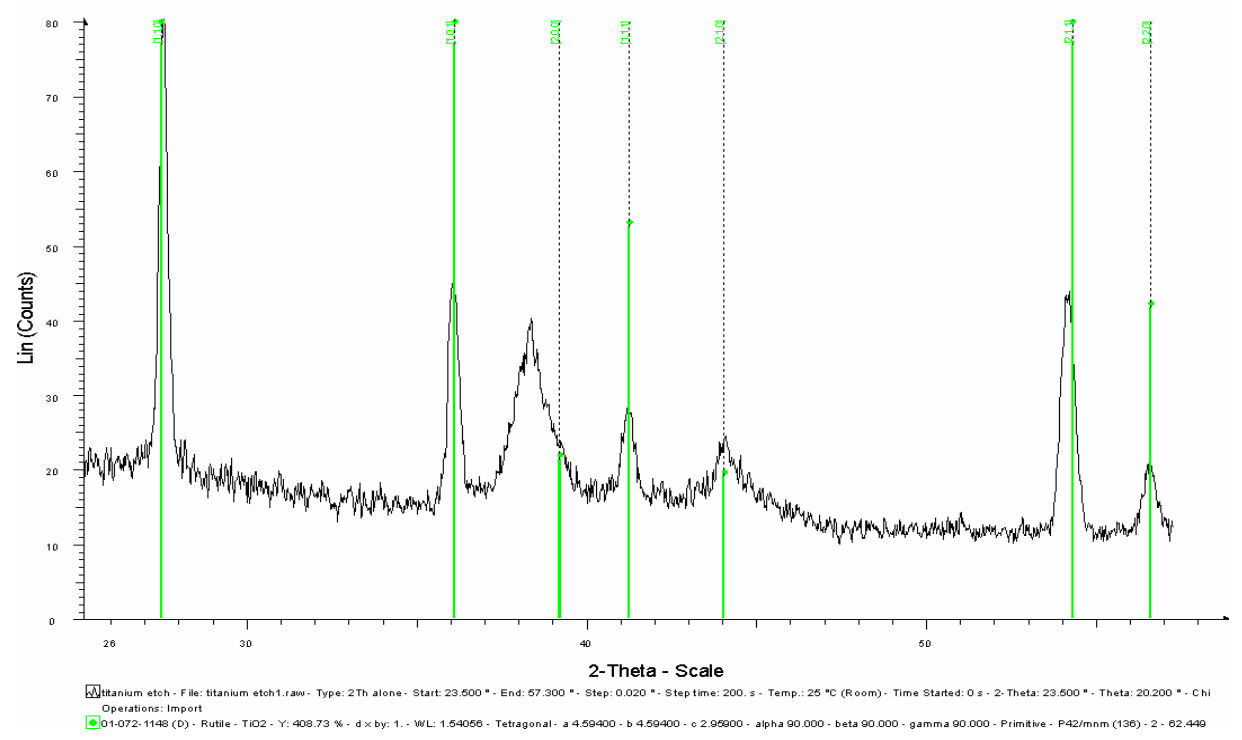

Figure 10 XRD pattern of titanium on quartz after gas carving

\section{CONCLUSIONS}

A simple method has been developed for producing nano-structured titanium oxide thin films using $\mathrm{H}_{2}$ gas interaction with titanium at high temperatures. Our experiments revealed that $\mathrm{H}_{2}$ gas can carve Ti film into nanorods at temperatures 
below $700^{\circ} \mathrm{C}$. On the contrary, at higher temperatures plate type structures appeared. $\mathrm{H}_{2}$ did not have any effect on $\mathrm{Ti}$

films at temperatures less than $600^{\circ} \mathrm{C}$. This work describes a simple way of shaping Ti films into nanostructured form of titanium oxide. Such films have numerous applications in electronics, optical, sensing and device fabrication industries.

\section{REFERENCES}

1. $\mathrm{Yu}, \mathrm{X}$., et al., Formation of nanoporous titanium oxide films on silicon substrates using an anodization process. Nanotechnology, 2006. 17: p. 808-814.

2. $\quad$ Grätzel, M., Photoelectrochemical cells. Nature, 2001. 414(6861): p. 338-344.

3. Birkefeld, L.D., A.M. Azad, and S.A. Akbar, Carbon Monoxide and Hydrogen Detection by Anatase Modification of Titanium Dioxide. Journal of the American Ceramic Society, 1992. 75(11): p. 2964.

4. Dutta, P.K., et al., Interaction of Carbon Monoxide with Anatase Surfaces at High Temperatures: Optimization of a Carbon Monoxide Sensor. J. Phys. Chem. B, 1999. 103: p. 4412-4422.

5. SUM, K. and S. T, Photoresponse of n-TiO2 thin film and nanowire electrodes. Solar Energy Materials and Solar Cells, 2003. 76(2): p. 211-221.

6. Yi, D.K. and D.-Y. Kim, Novel Approach to the Fabrication of Macroporous Polymers and Their Use as a Template for Crystalline Titania Nanorings. Nanoletters, 2003. 3(2): p. 207-211.

7. Yang, B., et al., Preparation of bioactive titanium metal via anodic oxidation treatment. Biomaterials, 2004. 25: p. 1003-10.

8. Imhof, A. and D.J. Pine, Ordered macroporous materials by emulsion templating. Nature, 1997. 389(6654): $\mathrm{p}$. 948-951.

9. Pan, Z.W., Z.R. Dai, and Z.L. Wang, Nanobelts of Semiconducting Oxides. Science, 2001. 291(5510): p. 19471949.

10. Yoo, S., S.A. Akbar, and K.H. Sandhage, Nanocarving of titania (TiO2): a novel approach for fabricating chemical sensing platform. Ceramics International, 2004. 30: p. 1121-1126.

*dhawand3@yahoo.com; fax +61 399252007 